\title{
Badania nad możliwością zastosowania cementów specjalnych do uszczelniania kolumn rur okładzinowych
}

\begin{abstract}
Uszczelnienie kolumn rur okładzinowych wymaga zastosowania zaczynów cementowych o odpowiednio dobranych parametrach reologicznych, zerowym odstoju wody oraz o właściwym dla danej głębokości czasie gęstnienia. Również powstały po związaniu stwardniały kamień cementowy powinien odznaczać się wysokimi parametrami mechanicznymi i jak najmniejszą przepuszczalnością dla gazu. Bardzo istotne jest prowadzenie szczegółowych badań nad doborem odpowiednich receptur zaczynów do warunków geologicznych, jakie panują w danym rejonie na dnie otworu wiertniczego. Opracowanie odpowiednich składów wymaga realizowania innowacyjnych badań laboratoryjnych nad doborem odpowiednich rodzajów środków chemicznych i materiałów uszczelniających, wpływających na polepszenie parametrów mechanicznych otrzymanych $\mathrm{z}$ nich kamieni cementowych. Celem zaprezentowanych w artykule badań była analiza możliwości zastosowania cementów specjalnych do uszczelniania kolumn rur okładzinowych oraz wynikających z tego różnic. $Z$ wybranych do badań składów dotychczas stosowanych $w$ przemyśle opracowano analogiczne receptury, jednak na bazie dwóch różnych cementów specjalnych. Podjęto również wstępne próby sporządzenia zaczynów cementowych na bazie wody i oleju. Zaczyny cementowe oraz otrzymane z nich próbki kamieni cementowych poddano badaniom technologicznym w celu określenia wpływu różnych cementów na ewentualne rozbieżności w wynikach. Zastosowanie w składach zaczynów cementowych spoiw wiążących dotychczas wykorzystywanych głównie w budownictwie pokazało możliwości wynikające $\mathrm{z}$ takiego rozwiązania oraz poszerzyło wiedzę na ten temat. Ponadto użycie w składach zaczynów cementowych dodatków o zróżnicowanej wielkości uziarnienia wpłynęło dodatkowo na lepsze wypełnienie przestrzeni międzyziarnowej matrycy cementowej oraz na zmniejszenie przepuszczalności kamieni cementowych. Zinterpretowanie uzyskanych wyników badań laboratoryjnych pozwoli na wytypowanie odpowiednich składów zaczynów cementowych na bazie cementów specjalnych, mogących znaleźć zastosowanie podczas uszczelniania otworów wiertniczych po użyciu różnych płuczek wiertniczych [3, 9-11].
\end{abstract}

Słowa kluczowe: zaczyn cementowy, kamień cementowy, parametry mechaniczne, parametry technologiczne, cementy specjalne.

\section{Research on the possibility of using special cements for sealing casing columns}

Sealing casing requires the use of cement slurries with appropriate rheological parameters, zero free water and adequate thickening time for a given depth. Also hardened cement stone, should be characterized by high mechanical parameters and minimal gas permeability. It is very important to conduct detailed research on the selection of suitable cement slurry recipes for the geological conditions that occur at the bottom of the borehole. The development of appropriate cement slurry recipes, requires the implementation of innovative laboratory tests on the selection of applicable types of chemicals and sealing materials, that improve the mechanical parameters of cement stones obtained from them. The aim of the research presented in this paper was to investigate the possibility of using special cements to seal the casing and the resulting differences. From the selected recipes used in industrial conditions, have been developed analogous recipes have been developed, however, based on two different special cements. Preliminary attempts have also been made to prepare oil based cement slurries. Cement slurries and cement stones obtained from them were subjected to technological tests to determine the effect of various cements on possible discrepancies in the results. The use of cement binders in the composition of cement slurries, used so far mainly in the construction industry, has shown the possibilities resulting from such a solution and has broadened the knowledge about them. Moreover, the application of additives with different grain size, resulted in better filling of the intergranular space of cement matrix and reducing the permeability of the cement stones. Interpretation of the results of laboratory tests, will allow to select appropriate cement slurry compositions, based on special cements which can be used for sealing of boreholes after using different drilling muds.

Key words: cement slurry, cement stone, mechanical parameters, technological parameters, special cements. 


\section{Wprowadzenie}

Obecnie w rejonie przedgórza Karpat firmy cementacyjne podczas zabiegów uszczelniania kolumn rur okładzinowych stosują głównie dwa rodzaje cementów: cement portlandzki CEM I oraz cement wiertniczy G. Większość przeprowadzonych zabiegów cementowania otworów wiertniczych kończyła się powodzeniem, a zastosowane zaczyny cementowe charakteryzowały się dobrymi parametrami technologicznymi. Zdarzały się jednak przypadki nieudanych cementowań, w których stosowane zaczyny cementowe miały źle dobrane składniki, wpływające na pogorszenie parametrów reologicznych oraz osłabienie płaszcza cementowego.

Uszczelnienie kolumny rur okładzinowych w każdym otworze wiertniczym wymaga zastosowania specjalnie opracowanego i dobranego do danych warunków geologiczno-technicznych zaczynu cementowego. Wiercone otwory mogą różnić się od siebie między innymi: głębokością, trajektorią, średnicą, rodzajem przewiercanych skał oraz ich przeznaczeniem. Wykonywanie otworów wiertniczych odbywać się może również przy udziale różnych płuczek wiertniczych, zarówno wodnodyspersyjnych, jak i olejowodyspersyjnych. Na spodzie każdego odwiertu panują również zróżnicowane wielkości ciśnienia i temperatury.

Wszystkie te czynniki mają znaczenie podczas opracowywania i sporządzania zaczynów cementowych, które powinny charakteryzować się odpowiednią gęstością, reologią, zerowym odstojem wody, jak najniższą filtracją i optymalnym czasem gęstnienia, w celu ich bezpiecznego zatłoczenia do otworu wiertniczego. Nie tylko właściwości zaczynu cementowego są istotne podczas zabiegów uszczelniania kolumn rur okładzinowych, ale ważne są również parametry mechaniczne powstałego z niego kamienia cementowego. Utworzony z zaczynu kamień cementowy powinien ustanowić $\mathrm{w}$ przestrzeni pozarurowej zbitą i szczelną barierę, odporną na działające w otworze siły (między innymi ściskające, zginające i inne), oraz być nieprzepuszczalny dla wszelkich dopływających mediów.

Na rynku krajowym istnieje wiele firm produkujących różnego rodzaju cementy, zarówno powszechnego użytku, jak i cementy specjalne, posiadające charakterystyczne dla siebie właściwości. Szeroki wachlarz dostępnych cementów daje możliwość opracowania zaczynów cementowych nie tylko na bazie cementów powszechnie wykorzystywanych w wiertnictwie, ale i tych, które do tej pory były pomijane przy tworzeniu składów zaczynów uszczelniających. Możliwość zastosowania innych niż dotychczas cementów pozwoli również na opracowanie zaczynów cementowych, które będzie można z powodzeniem wykorzystać w otworach wierconych nie tylko w rejonie południowo-wschodniej Polski. Badania poszerzą także naszą wiedzę na temat możliwości stworzenia zaczynów cementowych z dodatkiem oleju, mogących posłużyć do uszczelnienia kolumn rur wiertniczych po zastosowaniu płuczki inwersyjnej.

Po przeanalizowaniu sporej liczby składów zaczynów cementowych stosowanych przez serwisy cementacyjne oraz weryfikacji ich parametrów technologicznych wybrano te o najlepszych właściwościach, które posłużyły do wykonania części badań laboratoryjnych $[6,8,12,13]$.

\section{Badania laboratoryjne}

W artykule zamieszczono wyniki badań wybranych składów zaczynów cementowych, jak i otrzymanych z nich kamieni cementowych. Jako wody zarobowej użyto wody wodociągowej. Do sporządzania mieszanin wykorzystane zostały dwa rodzaje cementów powszechnie stosowanych w przemyśle naftowym (cement portlandzki CEM I 32,5 R oraz cement wiertniczy G) oraz dwa rodzaje cementów specjalnych (cement portlandzki popiołowy CEM II/B-V 32,5 N-LH/HSR/NA oraz cement hutniczy CEM III/A 32,5 N-LH/HSR/NA), mikrocement, a także inne dodatki wpływające na parametry zaczynów i kamieni cementowych. Głębokość występowania pokładów gazu ziemnego w rejonie południowo-wschodniej Polski wynosi od kilkudziesięciu metrów do około $2500 \mathrm{~m}$, dlatego badania przeprowadzono dla trzech różnych temperatur, jakie mogą występować na tych głębokościach: $25^{\circ} \mathrm{C}$, $35^{\circ} \mathrm{C}$ i $45^{\circ} \mathrm{C}$. W dalszej części przedstawiono wstępne wyniki badań zaczynów i kamieni cementowych, jakie otrzymano podczas prób sporządzania zaczynów cementowych na bazie wody i oleju, które mogłyby posłużyć do uszczelniania kolumn rur okładzinowych po wcześniejszym zastosowaniu w otworze płuczki olejowej. Zaczyny z dodatkiem oleju wykonano na bazie dwóch cementów: cementu portlandzkiego CEM I 32,5 R oraz cementu glinowego. Do badań wykorzystano olej mineralny, charakteryzujący się niską lepkością, temperaturą wrzenia powyżej $200^{\circ} \mathrm{C}$ i niską zawartością związków aromatycznych, poniżej 0,2\%. Wybrano olej najczęściej wykorzystywany podczas sporządzania płuczek inwersyjnych. Badania prowadzono dla dwóch temperatur: $25^{\circ} \mathrm{C}$ i $120^{\circ} \mathrm{C}[4,15-17]$.

Po sporządzeniu zaczynów cementowych mierzono ich:

- gęstość,

- rozlewność,

- parametry reologiczne,

- odstój wody,

- filtrację,

- czas gęstnienia. 
Zaczyny z dodatkiem oleju poddano badaniu:

- gęstości,

- filtracji,

- czasu wiązania,

- elektrycznej stabilności emulsyjnej (ES, [V]).

Po przeprowadzeniu badań laboratoryjnych parametrów zaczynów cementowych sporządzono z nich próbki kamieni cementowych. Próbki utwardzano przez 48 godzin w środowisku o określonej temperaturze i ciśnieniu (warunki otworopodobne). Następnie umieszczano je w autoklawach wykonanych ze stali nierdzewnej i przez cały okres sezonowania przetrzymywano w cieplarce.

Otrzymane kamienie cementowe po założonym czasie poddawano badaniom:

- wytrzymałości na ściskanie,

- wytrzymałości na zginanie,

- przyczepności do rur stalowych,

- porowatości,

- przepuszczalności dla gazu.

Próbki kamieni cementowych z dodatkiem oleju poddano badaniu wytrzymałości na ściskanie.

Poniżej w tablicach i na rysunkach przedstawiono szczegółowe wyniki badań właściwości reologicznych zaczynów cementowych oraz zmieniających się w czasie parametrów mechanicznych kamieni cementowych.

Niepewność uzyskanych wyników pomiarów zaprezentowanych poniżej oznaczono na podstawie klasy dokładności urządzeń pomiarowych na poziomie: dla pomiarów reologicz- nych $-0,2 \%$, dla pomiarów wytrzymałości na ściskanie, zginanie, pomiarów przyczepności do rur - 0,4\%, dla porowatości - 0,0001\%, dla przepuszczalności - 0,001\%.

Sklad zaczynu cementowego bazowego wraz z udzialem procentowym poszczególnych skladników (w stosunku do suchego cementu) dla temperatury $25^{\circ} \mathrm{C}$ :

1. w/c - 0,49; odpieniacz - 0,5\%; upłynniacz - 0,2\%; środek obniżający filtrację - 0,2\%; środek regulujący czas wiązania - 3,0\%; $\mathrm{KCl}-3,0 \%$ (w stosunku do w/c); lateks $-10,0 \%$; stabilizator lateksu $-1,0 \%$; mikrocement $-20,0 \%$; cement $-100 \%$; środek spęczniający $-0,3 \%$.

W tablicy 1 zestawiono wyniki badań przykładowego zaczynu cementowego wykorzystywanego przez serwis cementacyjny do uszczelniania kolumn rur okładzinowych dla temperatury $25^{\circ} \mathrm{C}$ (skład 1) oraz analogiczne składy sporządzone na bazie cementów specjalnych (składy 1a, 1b). Zastosowanie cementu CEM II/B-V wpłynęło na obniżenie rozlewności oraz gęstości, natomiast znacznie wzrosła filtracja zaczynu cementowego. Czasy gęstnienia zaczynu nieznacznie różniły się w porównaniu z zaczynem z cementem bazowym. Cement CEM III/A wpłynął na obniżenie gęstości oraz filtracji zaczynu, natomiast nieznacznie wzrosła rozlewność. Czas końca gęstnienia wydłużył się o ponad dwie godziny.

W tablicy 2 zestawiono wyniki zmierzonych parametrów mechanicznych kamieni cementowych oraz ich zmiany wraz z upływem czasu. Najwyższe wartości po 28 dniach sezonowania próbek dla wytrzymałości na ściskanie oraz przyczepności

Tablica 1 . Parametry technologiczne zaczynów cementowych dla temperatury $25^{\circ} \mathrm{C}$

\begin{tabular}{|c|c|c|c|c|c|c|c|}
\hline \multirow{2}{*}{ Skład } & Cement & $\begin{array}{c}\text { Rozlewność } \\
{[\mathrm{mm}]}\end{array}$ & $\begin{array}{c}\text { Gęstość } \\
{\left[\mathrm{g} / \mathrm{cm}^{3}\right]}\end{array}$ & $\begin{array}{c}\text { Odstój wody } \\
{[\%]}\end{array}$ & $\begin{array}{c}\text { Filtracja } \\
{\left[\mathrm{cm}^{3} / 30 \mathrm{~min}\right]}\end{array}$ & \multicolumn{3}{|c|}{$\begin{array}{c}\text { Czas gęstnienia } \\
{[\mathrm{h}: \mathrm{min}]}\end{array}$} \\
\cline { 5 - 9 } & CEM I & 220 & 1,82 & 0,0 & 34,0 & $2: 25$ & $2: 57$ \\
\hline 1 & CEM II/B-V & 200 & 1,76 & 0,0 & 106,0 & $2: 11$ & $2: 41$ \\
\hline $1 \mathrm{a}$ & CEM III/A & 230 & 1,77 & 0,0 & 32,0 & $3: 46$ & $4: 50$ \\
\hline
\end{tabular}

\begin{tabular}{|l|}
\hline Cement CEM I 32,5R \\
\hline Cement CEM II/B-V 32,5 N-LH/HSR/NA \\
\hline Cement CEM III/A 32,5 N-LH/HSR/NA \\
\hline
\end{tabular}

Tablica 2. Zmiany parametrów mechanicznych kamieni cementowych w czasie dla $25^{\circ} \mathrm{C}$

\begin{tabular}{|c|c|c|c|c|c|c|c|c|c|c|c|c|}
\hline \multirow{2}{*}{ Skład } & \multicolumn{4}{|c|}{$\begin{array}{l}\text { Wytrzymałość na ściskanie } \\
{[\mathrm{MPa}]}\end{array}$} & \multicolumn{4}{|c|}{$\begin{array}{l}\text { Wytrzymałość na zginanie } \\
{[\mathrm{MPa}]}\end{array}$} & \multicolumn{4}{|c|}{$\begin{array}{c}\text { Przyczepność do rur stalowych } \\
{[\mathrm{MPa}]}\end{array}$} \\
\hline & $\begin{array}{c}\text { po } 2 \\
\text { dniach }\end{array}$ & $\begin{array}{c}\text { po } 7 \\
\text { dniach }\end{array}$ & $\begin{array}{l}\text { po } 14 \\
\text { dniach }\end{array}$ & $\begin{array}{l}\text { po } 28 \\
\text { dniach }\end{array}$ & $\begin{array}{c}\text { po } 2 \\
\text { dniach }\end{array}$ & $\begin{array}{c}\text { po } 7 \\
\text { dniach }\end{array}$ & $\begin{array}{l}\text { po } 14 \\
\text { dniach }\end{array}$ & $\begin{array}{l}\text { po } 28 \\
\text { dniach }\end{array}$ & $\begin{array}{c}\text { po } 2 \\
\text { dniach }\end{array}$ & $\begin{array}{c}\text { po } 7 \\
\text { dniach }\end{array}$ & $\begin{array}{l}\text { po } 14 \\
\text { dniach }\end{array}$ & $\begin{array}{l}\text { po } 28 \\
\text { dniach }\end{array}$ \\
\hline 1 & 12,0 & 23,0 & 26,3 & 35,0 & 10,5 & 10,5 & 10,5 & 12,0 & 2,0 & 3,0 & 3,8 & 4,6 \\
\hline 1a & 15,0 & 16,0 & 25,5 & 29,3 & 9,0 & 10,5 & 10,5 & 12,0 & 2,6 & 3,2 & 3,9 & 4,4 \\
\hline $1 b$ & 7,3 & 13,6 & 26,5 & 31,9 & 9,0 & 10,5 & 10,5 & 10,5 & 1,8 & 2,5 & 3,5 & 4,3 \\
\hline
\end{tabular}




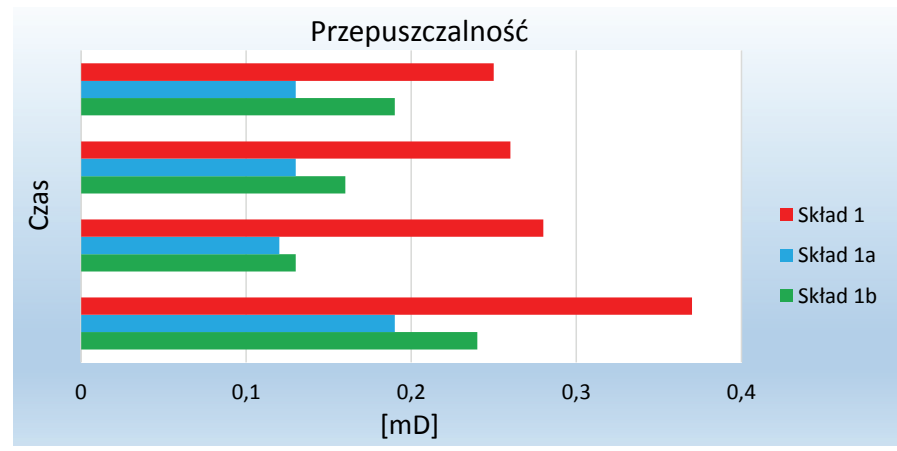

Rys. 1. Zmiany przepuszczalności dla gazu w czasie (próbki 1, 1a, 1b)

do rur stalowych odnotowano w przypadku zaczynu bazowego z udziałem cementu portlandzkiego CEM I. Różnice w wytrzymałości kamieni cementowych na zginanie po każdym okresie badań były natomiast znikome. Na rysunkach 1 i 2 przedstawiono porównanie przepuszczalności dla gazu oraz porowatości próbek kamieni cementowych 1, 1a i 1 b.

Pomiary przepuszczalności dla gazu wykazały, że dla każdego rodzaju cementu między 2. a 28. dniem od sporządzenia próbek kamieni cementowych przepuszczalności zmalały. Po każdym okresie badań najwyższą przepuszczalnością odznaczał się jednak skład 1 na bazie cementu CEM I (po 28 dniach około $0,25 \mathrm{mD}$ ). Najniższą przepuszczalność po 28 dniach posiadał kamień wykonany na bazie cementu portlandzkiego popiołowego - wynosiła ona $0,13 \mathrm{mD}$.

Porowatości kamieni cementowych $1,1 \mathrm{a}, 1 \mathrm{~b}$ po 2 dniach ich hydratacji były wysokie i wynosiły od 34,4\% (skład 1$)$ do 42,4\% (skład 1b). Następnie wraz z upływem czasu wartości te uległy obniżeniu i po 28 dniach wynosiły od około $30,6 \%$ (skład $1 \mathrm{~b}$ - odnotowano największe obniżenie porowatości) do $35,0 \%$ ( $(k ł a d 1 \mathrm{a}$ - najniższy spadek porowatości).

Sklad zaczynu cementowego bazowego wraz z udzialem procentowym poszczególnych skladników (w stosunku do suchego cementu) dla temperatury $35^{\circ} \mathrm{C}$ :

2. w/c - 0,48; odpieniacz - $0,5 \%$; upłynniacz - $0,3 \%$; środek obniżający filtrację $-0,2 \%$; środek regulujący czas

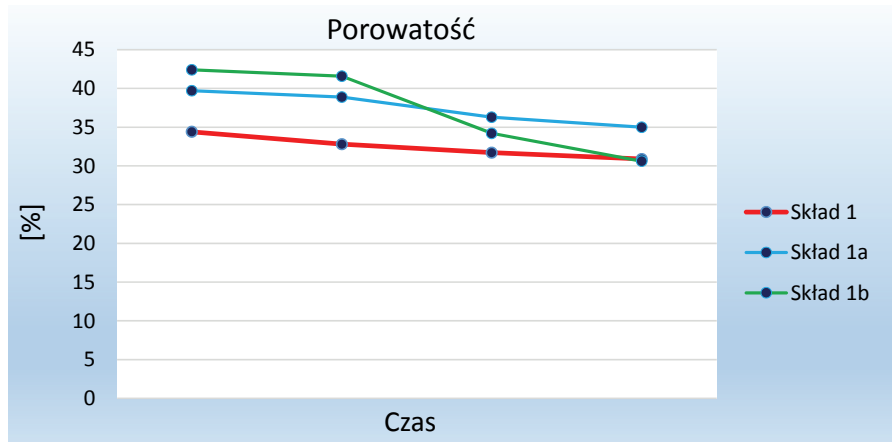

Rys. 2. Zmiany porowatości w czasie (próbki 1, 1a, 1b)

wiązania $-0,05 \% ; \mathrm{KCl}-3,0 \%$ (w stosunku do w/c); lateks $-8,0 \%$; stabilizator lateksu $-1,0 \%$; mikrocement $-10,0 \%$; cement $-100 \%$; środek spęczniający $-0,1 \%$. $\mathrm{W}$ tablicy 3 zestawiono wyniki badań trzech składów zaczynów cementowych dla temperatury $35^{\circ} \mathrm{C}$. Zastosowanie cementu CEM II/B-V wpłynęło na obniżenie rozlewności oraz gęstości, natomiast znacznie wzrosła filtracja: $\mathrm{z} 32,0 \mathrm{~cm}^{3} / 30 \mathrm{~min}$ do $179,0 \mathrm{~cm}^{3} / 30 \mathrm{~min}$. Zaczyn 2a posiadał również niewielki odstój wody. Czas początku gęstnienia zaczynu cementowego był zbliżony do tego, jaki osiągnął zaczyn bazowy, natomiast jego koniec wydłużył się o około 0,5 godziny. Cement hutniczy CEM III/A również wpłynął na obniżenie gęstości oraz rozlewności. Filtracja w przypadku składu $2 b$ także wzrosła, jednak nie była to aż tak wielka różnica jak w przypadku cementu popiołowego. Czasy początku i końca gęstnienia po zastosowaniu cementu CEM III/A znacznie się wydłużyły.

W tablicy 4 przedstawiono wpływ zastosowania różnych cementów na różnice w parametrach mechanicznych otrzymanych z nich kamieni cementowych. Najwyższe wartości po 28 dniach sezonowania próbek dla wytrzymałości na ściskanie oraz przyczepności do rur stalowych odnotowano w przypadku zaczynu z udziałem cementu CEM II/B-V (skład 2a - ściskanie: 40,8 MPa; przyczepność: 7,6 MPa). Najniższą wytrzymałość na ściskanie po 28 dniach odnotowano dla składu $\mathrm{z}$ udziałem cementu hutniczego CEM III/A (skład 2b: 30,8 MPa), zaś najmniejszą przyczepność do rur miał kamień wykonany z zaczynu

Tablica 3. Parametry technologiczne zaczynów cementowych dla temperatury $35^{\circ} \mathrm{C}$

\begin{tabular}{|c|c|c|c|c|c|c|c|}
\hline \multirow{2}{*}{ Skład } & \multirow{2}{*}{ Cement } & \multirow{2}{*}{$\begin{array}{c}\text { Rozlewność } \\
{[\mathrm{mm}]}\end{array}$} & \multirow{2}{*}{$\begin{array}{l}\text { Gęstość } \\
{\left[\mathrm{g} / \mathrm{cm}^{3}\right]}\end{array}$} & \multirow{2}{*}{$\begin{array}{c}\text { Odstój wody } \\
{[\%]}\end{array}$} & \multirow{2}{*}{$\begin{array}{c}\text { Filtracja } \\
{\left[\mathrm{cm}^{3} / 30 \mathrm{~min}\right]}\end{array}$} & \multicolumn{2}{|c|}{$\begin{array}{c}\text { Czas gęstnienia } \\
\text { [h:min] }\end{array}$} \\
\hline & & & & & & $30 \mathrm{Bc}$ & $100 \mathrm{Bc}$ \\
\hline 2 & CEM I & 240 & 1,81 & 0,0 & 32,0 & $2: 55$ & $3: 28$ \\
\hline $2 \mathrm{a}$ & CEM II/B-V & 230 & 1,73 & 0,4 & 179,0 & $3: 01$ & $4: 01$ \\
\hline $2 b$ & CEM III/A & 220 & 1,75 & 0,0 & 60,0 & $3: 53$ & $6: 24$ \\
\hline
\end{tabular}

\begin{tabular}{|l|}
\hline Cement CEM I 32,5R \\
\hline Cement CEM II/B-V 32,5 N-LH/HSR/NA \\
\hline Cement CEM III/A 32,5 N-LH/HSR/NA \\
\hline
\end{tabular}


Tablica 4. Zmiany parametrów mechanicznych kamieni cementowych w czasie dla temperatury $35^{\circ} \mathrm{C}$

\begin{tabular}{|c|c|c|c|c|c|c|c|c|c|c|c|c|}
\hline \multirow{2}{*}{ Skład } & \multicolumn{4}{|c|}{$\begin{array}{c}\text { Wytrzymałość na ściskanie } \\
{[\mathrm{MPa}]}\end{array}$} & \multicolumn{4}{|c|}{$\begin{array}{l}\text { Wytrzymałość na zginanie } \\
\qquad[\mathrm{MPa}]\end{array}$} & \multicolumn{4}{|c|}{$\begin{array}{c}\text { Przyczepność do rur stalowych } \\
{[\mathrm{MPa}]}\end{array}$} \\
\hline & $\begin{array}{c}\text { po } 2 \\
\text { dniach }\end{array}$ & $\begin{array}{c}\text { po } 7 \\
\text { dniach }\end{array}$ & $\begin{array}{l}\text { po } 14 \\
\text { dniach }\end{array}$ & $\begin{array}{l}\text { po } 28 \\
\text { dniach }\end{array}$ & $\begin{array}{c}\text { po } 2 \\
\text { dniach }\end{array}$ & $\begin{array}{c}\text { po } 7 \\
\text { dniach }\end{array}$ & $\begin{array}{l}\text { po } 14 \\
\text { dniach }\end{array}$ & $\begin{array}{l}\text { po } 28 \\
\text { dniach }\end{array}$ & $\begin{array}{c}\text { po } 2 \\
\text { dniach }\end{array}$ & $\begin{array}{c}\text { po } 7 \\
\text { dniach }\end{array}$ & $\begin{array}{l}\text { po } 14 \\
\text { dniach }\end{array}$ & $\begin{array}{l}\text { po } 28 \\
\text { dniach }\end{array}$ \\
\hline 2 & 14,0 & 22,5 & 30,9 & 32,4 & 9,0 & 9,0 & 10,5 & 10,5 & 2,7 & 4,1 & 4,8 & 5,0 \\
\hline $2 \mathrm{a}$ & 16,7 & 32,1 & 34,5 & 40,8 & 10,5 & 10,5 & 12,0 & 12,0 & 3,7 & 5,8 & 6,7 & 7,6 \\
\hline $2 b$ & 12,5 & 30,5 & 31,5 & 30,8 & 10,5 & 10,5 & 12,0 & 12,0 & 2,3 & 3,0 & 5,6 & 7,0 \\
\hline
\end{tabular}

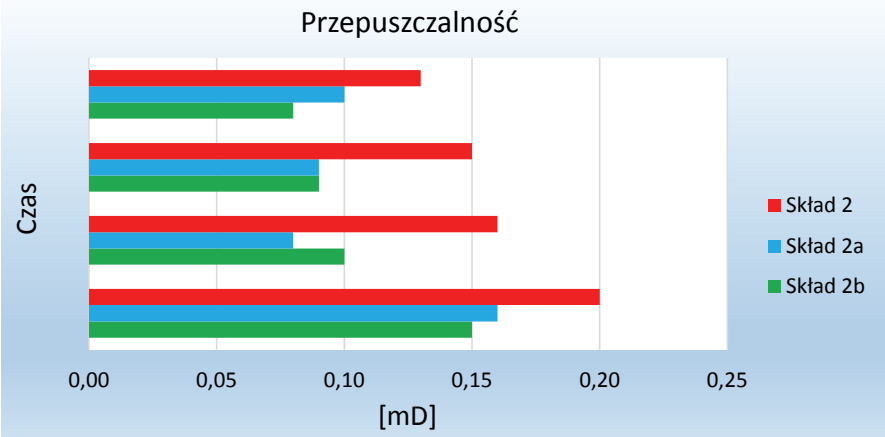

Rys. 3. Zmiany przepuszczalności dla gazu w czasie (próbki 2, 2a, 2b)

bazowego (skład 2 - 5,0 MPa). Wytrzymałości kamieni cementowych na zginanie po każdym okresie badań były porównywalne. Rysunki 3 oraz 4 ilustrują różnice w przepuszczalnościach oraz porowatościach badanych próbek w $35^{\circ} \mathrm{C}$.

Pomiary przepuszczalności dla gazu wykazały, że dwa składy: 2 i $2 b$ wraz z upływem czasu posiadały coraz niższą przepuszczalność. Przepuszczalność próbki 2a przez pierwsze 7 dni również ulegała obniżeniu, jednak po tym czasie zaczęła wzrastać. Po 28 dniach najniższą przepuszczalność dla gazu miał kamień cementowy wykonany ze składu $2 \mathrm{~b}$, wyniosła ona około $0,08 \mathrm{mD}$.

Najniższą porowatość po 2 i 7 dniach hydratacji posiadał kamień cementowy zawierający w składzie cement CEM I (skład 2). Po 14 dniach porowatości wszystkich trzech próbek były zbliżone i wynosiły około 33,5\%. Kolejny pomiar po 28 dniach od sporządzenia próbek kamieni cementowych wykazał, że porowatość próbki bazowej (2) była wyższa od tych z zawartością cementów specjalnych (2a, 2b). Największy spadek porowatości odnotowano w przypadku próbki $2 \mathrm{~b}$ : od $39,1 \%$ po 2 dniach do $31,1 \%$ po 28 dniach.

Sktad zaczynu cementowego bazowego wraz z udziatem procentowym poszczególnych skladników (w stosunku do suchego cementu) dla temperatury $45^{\circ} \mathrm{C}$ :

3 . w/c - 0,50; odpieniacz - 0,5\%; upłynniacz $-0,5 \%$; środek obniżający filtrację $-0,2 \%$; środek regulujący czas wiązania - $0,15 \% ; \mathrm{KCl}-3,0 \%$ (w stosunku do w/c); lateks $-10,0 \%$; stabilizator lateksu $-1,0 \%$; mikrocement $-20,0 \%$; cement $-100 \%$; środek spęczniający $-0,3 \%$.

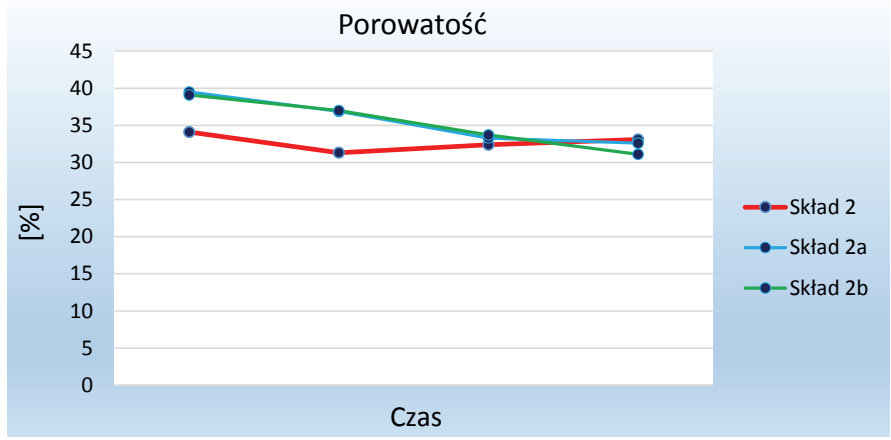

Rys. 4. Zmiany porowatości w czasie (próbki 2, 2a, 2b)

Dla temperatury $45^{\circ} \mathrm{C}$ wyniki badań technologicznych zaczynów cementowych przedstawiono w tablicy 5. Zastosowanie cementu popiołowego CEM II/B-V również w tym przypadku wpłynęło na obniżenie rozlewności oraz gęstości, wzrosła natomiast dwukrotnie filtracja. Czas końca gęstnienia zaczynu cementowego 3a był zbliżony do składu bazowego 3 . Użycie cementu hutniczego CEM III/A wpłynęło na obniżenie rozlewności, gęstości, jak również filtracji zaczynu cementowego. Czas początku gęstnienia znacznie się wydłużył, zaś koniec gęstnienia był dłuższy niż 8 godzin.

W tablicy 6 zestawiono wyniki zmierzonych parametrów mechanicznych kamieni cementowych oraz ich zmiany wraz $\mathrm{z}$ upływem czasu dla temperatury $45^{\circ} \mathrm{C}$. Najwyższe wartości po 28 dniach sezonowania próbek dla wytrzymałości na ściskanie oraz przyczepności do rur stalowych odnotowano w przypadku zaczynu z udziałem cementu CEM II/B-V (skład 3a-ściskanie: 43,5 MPa; przyczepność: 7,2 MPa). Najniższą wytrzymałość na ściskanie po 28 dniach zmierzono dla składu z udziałem cementu portlandzkiego CEM I (skład 3: 29,6 MPa). Najniższą przyczepność do rur po 28 dniach hydratacji miała próbka 3b, wynosiła ona 4,7 MPa. Wytrzymałości kamieni cementowych na zginanie po każdym okresie badań były porównywalne.

Pomiary przepuszczalności dla gazu wykazały, że tylko w przypadku dwóch składów (3 i 3a) między 2. a 28. dniem hydratacji przepuszczalność zmalała, natomiast dla próbki 3 b nastąpił wzrost przepuszczalności dla gazu z $0,18 \mathrm{mD}$ do $0,21 \mathrm{mD}$ - była to jednocześnie największa przepuszczalność, jaką odnotowano po 28 dniach sezonowania próbek w $45^{\circ} \mathrm{C}$. 
Tablica 5. Parametry technologiczne zaczynów cementowych dla temperatury $45^{\circ} \mathrm{C}$

\begin{tabular}{|c|c|c|c|c|c|c|c|}
\hline \multirow{2}{*}{ Skład } & Cement & $\begin{array}{c}\text { Rozlewność } \\
{[\mathrm{mm}]}\end{array}$ & $\begin{array}{c}\text { Gęstość } \\
{\left[\mathrm{g} / \mathrm{cm}^{3}\right]}\end{array}$ & $\begin{array}{c}\text { Odstój wody } \\
{[\%]}\end{array}$ & $\begin{array}{c}\text { Filtracja } \\
{\left[\mathrm{cm}^{3} / 30 \mathrm{~min}\right]}\end{array}$ & \multicolumn{2}{|c|}{$\begin{array}{c}\text { Czas gęstnienia } \\
{[\mathrm{h}: \mathrm{min}]}\end{array}$} \\
\cline { 5 - 9 } & CEM I & 220 & 1,81 & 0,0 & 48,0 & $4: 00$ & $4: 37$ \\
\hline 3 & CEM II/B-V & 200 & 1,76 & 0,0 & 92,0 & $3: 15$ & $4: 44$ \\
\hline $3 \mathrm{a}$ & CEM III/A & 175 & 1,77 & 0,0 & 13,0 & $6: 18$ & $>8 \mathrm{hc}$ \\
\hline
\end{tabular}

\begin{tabular}{|l|}
\hline Cement CEM I 32,5R \\
\hline Cement CEM II/B-V 32,5 N-LH/HSR/NA \\
\hline Cement CEM III/A 32,5 N-LH/HSR/NA \\
\hline
\end{tabular}

Tablica 6. Zmiany parametrów mechanicznych kamieni cementowych w czasie dla $45^{\circ} \mathrm{C}$

\begin{tabular}{|c|c|c|c|c|c|c|c|c|c|c|c|c|}
\hline \multirow{2}{*}{ Skład } & \multicolumn{4}{|c|}{$\begin{array}{c}\text { Wytrzymałość na ściskanie } \\
{[\mathrm{MPa}]}\end{array}$} & \multicolumn{4}{|c|}{$\begin{array}{l}\text { Wytrzymałość na zginanie } \\
{[\mathrm{MPa}]}\end{array}$} & \multicolumn{4}{|c|}{$\begin{array}{l}\text { Przyczepność do rur stalowych } \\
{[\mathrm{MPa}]}\end{array}$} \\
\hline & $\begin{array}{c}\text { po } 2 \\
\text { dniach }\end{array}$ & $\begin{array}{c}\text { po } 7 \\
\text { dniach }\end{array}$ & $\begin{array}{l}\text { po } 14 \\
\text { dniach }\end{array}$ & $\begin{array}{l}\text { po } 28 \\
\text { dniach }\end{array}$ & $\begin{array}{c}\text { po } 2 \\
\text { dniach }\end{array}$ & $\begin{array}{c}\text { po } 7 \\
\text { dniach }\end{array}$ & $\begin{array}{l}\text { po } 14 \\
\text { dniach }\end{array}$ & $\begin{array}{l}\text { po } 28 \\
\text { dniach }\end{array}$ & $\begin{array}{c}\text { po } 2 \\
\text { dniach }\end{array}$ & $\begin{array}{c}\text { po } 7 \\
\text { dniach }\end{array}$ & $\begin{array}{l}\text { po } 14 \\
\text { dniach }\end{array}$ & $\begin{array}{l}\text { po } 28 \\
\text { dniach }\end{array}$ \\
\hline 3 & 15,0 & 21,8 & 28,0 & 29,6 & 10,5 & 10,5 & 10,5 & 10,5 & 3,0 & 4,8 & 5,1 & 5,6 \\
\hline $3 a$ & 20,3 & 33,6 & 36,1 & 43,5 & 9,0 & 10,5 & 10,5 & 10,5 & 3,8 & 5,6 & 6,4 & 7,2 \\
\hline $3 b$ & 18,3 & 26,0 & 32,8 & 31,0 & 10,5 & 10,5 & 10,5 & 10,5 & 3,4 & 4,1 & 4,5 & 4,7 \\
\hline
\end{tabular}

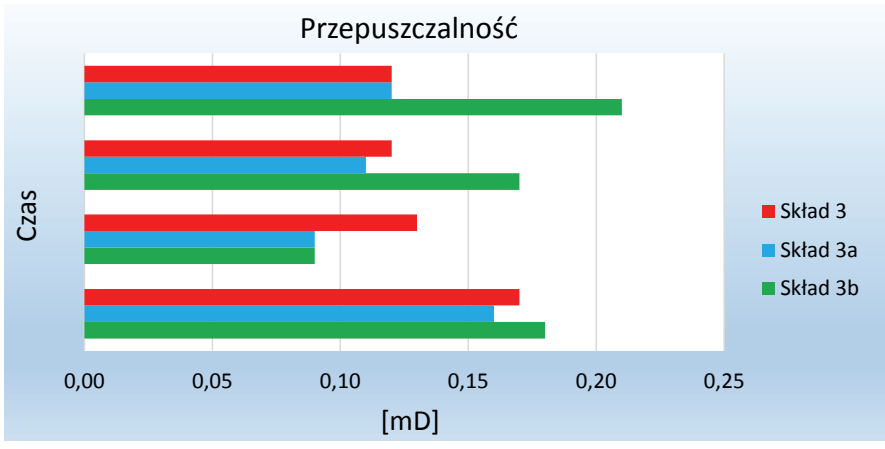

Rys. 5. Zmiany przepuszczalności dla gazu w czasie (próbki 3, 3a, 3b)

Najwyższą porowatość po 2 dniach sezonowania próbek posiadał kamień cementowy wykonany ze składu 3a, zawierający cement CEM II/B-V, i wynosiła ona 37,4\%, zaś najniższą porowatością odznaczał się skład bazowy 3 - 33,1\%. Po 28 dniach porowatości każdej z próbek były niższe niż na początku i wynosiły odpowiednio: skład $3-31,6 \%$, skład $3 a-33,3 \%$, skład $3 b-33,8 \%$.

Po realizacji pierwszej części badań laboratoryjnych przeprowadzono próby sporządzenia zaczynów cementowych na bazie wody i oleju. Wstępne badania wykonano na bazie dwóch rodzajów cementów i innych dodatków wpływających na poprawę parametrów zaczynów oraz ułatwiających wspólne połączenie się wszystkich składników w jedną mieszaninę. Poniżej zaprezentowano wybrane wyniki badań zarówno zaczynów, jak i otrzymanych z nich kamieni cementowych.

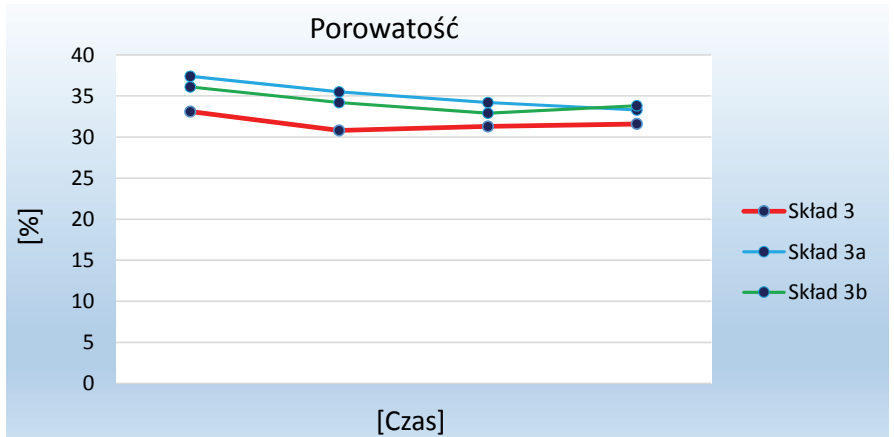

Rys. 6. Zmiany porowatości w czasie (próbki 3, 3a, 3b)

W tablicy 7 zestawiono wyniki parametrów wybranych zaczynów cementowych opracowanych na bazie wody i oleju. Pierwsze cztery składy przygotowano na cemencie portlandzkim CEM I, zaś kolejne cztery na cemencie glinowym. Do zaczynów cementowych dodawano upłynniacz (od 0,3\% do $0,5 \%$ ), środek powierzchniowo czynny (od 0,2\% do 0,5\%) oraz mieszaninę oleju (od 30\% do 65\%) i emulgatora (od $6,0 \%$ do $7,0 \%$ ).

Zaczyny cementowe sporządzone na bazie cementu portlandzkiego posiadały niższą gęstość od tych z cementem glinowym, natomiast znacznie wyższą filtrację. Przeprowadzone badania wykazały, że w większości przypadków występowały komplikacje podczas przygotowywania mieszaniny z cementem CEM I, między innymi dochodziło do szybkiego żelowania zaczynów, oddawania niewchłoniętej wody lub oleju. Zaczyny cementowe $\mathrm{z}$ cementem portlandzkim posiadały 
Tablica 7. Parametry zaczynów cementowych z dodatkiem oleju

\begin{tabular}{|c|c|c|c|c|c|c|c|c|c|c|c|}
\hline Skład & Cement & $\mathrm{w} / \mathrm{c}^{* * *}$ & $\begin{array}{c}\text { Upłynniacz } \\
{[\%]} \\
\text { (w stosunku } \\
\text { do cementu) }\end{array}$ & $\begin{array}{c}\text { SPC } \\
{[\%]} \\
\text { (w stos. } \\
\text { do } w / c \text { ) }\end{array}$ & $\begin{array}{c}\text { Olej } \\
{[\%]} \\
\text { (w stos. do } \\
\text { ilości wody) }\end{array}$ & $\begin{array}{l}\text { Emulgator } \\
{[\%]} \\
\text { (w stos. do } \\
\text { oleju) }\end{array}$ & $\begin{array}{l}\text { Gęstość } \\
{\left[\mathrm{g} / \mathrm{cm}^{3}\right]}\end{array}$ & $\begin{array}{c}\text { Filtracja } \\
{\left[\mathrm{cm}^{3} / 30\right.} \\
\min ]\end{array}$ & $\begin{array}{l}\text { PW } \\
{[\text { dni }]}\end{array}$ & $\begin{array}{l}\mathrm{KW} \\
{[\mathrm{dni}]}\end{array}$ & $\begin{array}{c}\text { Wskaźnik } \\
\text { ES } \\
{[\mathrm{V}]}\end{array}$ \\
\hline 1 & $\mathrm{P}^{*}$ & 0,50 & 0,3 & 0,4 & 30,0 & 6,0 & 1,62 & 296,0 & 1 & 2 & 1 \\
\hline 2 & $\mathrm{P}$ & 0,47 & 0,3 & 0,2 & 40,0 & 6,0 & 1,62 & 164,0 & 5 & 7 & 24 \\
\hline 3 & $\mathrm{P}$ & 0,40 & 0,3 & 0,5 & 50,0 & 6,0 & 1,63 & 82,0 & 1 & 2 & 3 \\
\hline 4 & $\mathrm{P}$ & 0,37 & 0,4 & 0,3 & 55,0 & 6,0 & 1,63 & 112,0 & 1 & 2 & 2 \\
\hline 5 & $\mathrm{G}^{* *}$ & 0,37 & 0,4 & 0,3 & 55,0 & 6,0 & 1,67 & 2,5 & 2 & 3 & 29 \\
\hline 6 & G & 0,40 & 0,3 & 0,3 & 60,0 & 6,0 & 1,66 & 3,0 & 3 & 4 & 44 \\
\hline 7 & G & 0,38 & 0,5 & 0,2 & 65,0 & 6,0 & 1,67 & 3,0 & 4 & 5 & 156 \\
\hline 8 & G & 0,38 & 0,5 & 0,2 & 62,0 & 7,0 & 1,68 & 2,5 & 4 & 5 & 132 \\
\hline
\end{tabular}

${ }^{*} \mathrm{P}$ - cement portlandzki CEM I

${ }^{* *} \mathrm{G}-$ cement glinowy

${ }^{* * *}$ w/c - stosunek wody do suchego cementu

SPC - środek powierzchniowo czynny

$\mathrm{PW}$ - początek wiązania

$\mathrm{KW}$ - koniec wiązania

również niską elektryczną stabilność emulsyjną (ES). Miało to ewidentny wpływ na krótsze czasy wiązania zaczynów cementowych (przeważnie im mniejszy wskaźnik ES, tym krótszy czas wiązania). Ponadto może to świadczyć o ewentualnym braku kompatybilności z płuczką inwersyjną (której ES jest większy od $300 \mathrm{~V}$ ), a co za tym idzie - i z osadami pozostawionymi przez nią na ścianach otworu wiertniczego. Inaczej było po zastosowaniu cementu glinowego, gdy w większej liczbie przypadków połączenie składników oraz otrzymanie jednorodnej mieszaniny było łatwiejsze i mniej kłopotliwe. Zastosowanie w zaczynach cementowych cementu glinowego wpłynęło na wzrost ich elektrycznej stabilności emulsyjnej. Wyższy wskaźnik ES był jednoznaczny z wydłużeniem się czasu wiązania zaczynów cementowych, a otrzymanym filtratem była emulsja wody z olejem (filtrat w zaczynach $z$ cementem portlandzkim stanowiła woda). Wraz ze wzrostem elektrycznej stabilności wzrastać może kompatybilność danego zaczynu cementowego z płuczką olejowodyspersyjną $[2,5,8,14]$.

Wyższą wytrzymałość na ściskanie posiadały próbki wykonane na cemencie CEM I. Wynikać to może $\mathrm{z}$ faktu, że te zaczyny cementowe $\mathrm{w}$ większości przypadków oddawały sporą ilość wody lub oleju w postaci odstoju. Na wyższą wytrzymałość wpływ miała również bardzo niska elek- tryczna stabilność emulsyjna. Dowodem jest np. fakt, że najniższą wytrzymałość miał kamień powstały z zaczynu o najwyższym wskaźniku ES.

Próbki wykonane z zaczynów zawierających cement glinowy po każdym okresie badań posiadały znacznie niższą wytrzymałość na ściskanie w porównaniu do tych z cementem portlandzkim. Wynika to z faktu, że np. podczas mieszania tworzyły jednolitą mieszaninę, nie posiadały odstoju i ich elektryczna stabilność była wyższa. Przykładem może być porównanie dwóch składów: 4 (cement CEM I) i 5 (cement glinowy), które były identyczne poza zastosowanym cementem, a otrzymane wytrzymałości znacznie się od siebie różniły.

Tablica 8. Wytrzymałość na ściskanie kamieni cementowych na bazie wody i oleju

\begin{tabular}{|c|c|c|c|c|c|c|}
\hline \multirow{2}{*}{ Skład } & \multicolumn{5}{|c|}{ Wytrzymałość na ściskanie [MPa] } \\
\cline { 2 - 7 } & \multicolumn{3}{|c|}{ temperatura $25^{\circ} \mathrm{C}$} & \multicolumn{3}{c|}{ temperatura $120^{\circ} \mathrm{C}$} \\
\cline { 2 - 7 } & $\begin{array}{c}\text { po 7 } \\
\text { dniach }\end{array}$ & $\begin{array}{c}\text { po 14 } \\
\text { dniach }\end{array}$ & $\begin{array}{c}\text { po 28 } \\
\text { dniach }\end{array}$ & $\begin{array}{c}\text { po 7 } \\
\text { dniach }\end{array}$ & $\begin{array}{c}\text { po 14 } \\
\text { dniach }\end{array}$ & $\begin{array}{c}\text { po 28 } \\
\text { dniach }\end{array}$ \\
\hline 1 & 3,2 & 5,6 & 6,4 & 4,4 & 8,6 & 9,4 \\
\hline 2 & 0,7 & 1,1 & 1,7 & 1,0 & 1,8 & 2,2 \\
\hline 3 & 7,1 & 12,4 & 13,8 & 9,2 & 14,3 & 16,0 \\
\hline 4 & 12,4 & 18,0 & 19,7 & 15,2 & 21,6 & 23,7 \\
\hline 5 & 2,1 & 3,6 & 3,8 & 1,6 & 2,2 & 2,4 \\
\hline 6 & 1,2 & 1,8 & 2,1 & 1,4 & 2,0 & 2,2 \\
\hline 7 & 1,7 & 2,4 & 2,6 & 2,0 & 2,4 & 2,5 \\
\hline 8 & 1,2 & 1,9 & 2,3 & 1,7 & 2,1 & 2,3 \\
\hline
\end{tabular}




\section{Wnioski i podsumowanie}

Na podstawie przeprowadzonych badań porównania zaczynów cementowych dotychczas stosowanych przez serwisy cementacyjne z tymi na bazie cementów specjalnych można wyciągnąć następujące wnioski:

1. Większość poddanych badaniom składów zaczynów cementowych charakteryzowała się dobrymi parametrami reologicznymi oraz zerowym odstojem wody.

2. Gęstości zaczynów cementowych wahały się w przedziale od $1,73 \mathrm{~g} / \mathrm{cm}^{3}$ do $1,82 \mathrm{~g} / \mathrm{cm}^{3}$.

3. Zastosowanie w zaczynach cementowych cementów dotychczas niewykorzystywanych w przemyśle wpłynęło na obniżenie ich gęstości.

4. Cement portlandzki popiołowy (CEM II/B-V) w każdym przypadku wpływał na obniżenie rozlewności oraz na znaczny wzrost filtracji zaczynów cementowych.

5. Filtracje zaczynów bazowych wynosily od $32,0 \mathrm{~cm}^{3} / 30 \mathrm{~min}$ do $48,0 \mathrm{~cm}^{3} / 30 \mathrm{~min}$, natomiast zaczynów na bazie cementu CEM II/B-V od $92,0 \mathrm{~cm}^{3} / 30 \mathrm{~min}$ do $179,0 \mathrm{~cm}^{3} / 30 \mathrm{~min}$.

6. Czasy gęstnienia po zastosowaniu cementu popiołowego nieznacznie odbiegały od tych, które osiągały zaczyny bazowe, jednak można je regulować odpowiednimi środkami.

7. Kamienie cementowe wykonane z zaczynów cementowych na bazie cementu portlandzkiego popiołowego posiadały bardzo wysokie wytrzymałości na ściskanie, zginanie oraz dobrą przyczepność do rur stalowych.

8. Po 28 dniach wytrzymałość na ściskanie przekraczała 29,3 MPa (skład 1a) i dochodziła nawet do 43,5 MPa (skład 3a), wytrzymałość na zginanie dochodziła do $12 \mathrm{MPa}$, zaś przyczepność do rur stalowych mieściła się w granicach od 4,4 MPa do 7,6 MPa (skład 2a).

9. Większość kamieni cementowych zawierających w składzie cement CEM II/B-V odznaczała się mniejszą przepuszczalnością dla gazu, jednak większą porowatością w porównaniu z tymi samymi składami, ale na bazie cementów powszechnego użytku.

10. Zastosowanie cementu hutniczego (CEM III/A) w większości składów nie wpłynęło na zmianę rozlewności za wyją̧tkiem zaczynów badanych $\mathrm{w} 45^{\circ} \mathrm{C}$, w przypadku których uległa ona obniżeniu.

11. Filtracje zaczynów z dodatkiem cementu CEM III/A wynosity od $13,0 \mathrm{~cm}^{3} / 30 \mathrm{~min}$ do $60,0 \mathrm{~cm}^{3} / 30 \mathrm{~min}$ i za wyjątkiem składu $2 \mathrm{~b}\left(35^{\circ} \mathrm{C}\right)$ były niższe od tych uzyskiwanych przez zaczyny bazowe.

12. Czasy końca gęstnienia zaczynów cementowych sporządzonych na bazie cementu hutniczego w każdym przypadku były sporo dłuższe od tych, jakie posiadały zaczyny wykonane na cementach powszechnego użytku.
13. Kamienie cementowe powstałe z zaczynów cementowych na bazie cementu hutniczego posiadały również wysokie wytrzymałości na ściskanie, zginanie oraz dobrą przyczepność do rur stalowych. W większości przypadków wartości te były jednak niższe od tych, jakie uzyskiwano, wykorzystując pozostałe cementy.

14. Po 28 dniach wytrzymałość na ściskanie przekraczała 30,0 MPa. Wytrzymałość na zginanie przeważnie wynosiła $12 \mathrm{MPa}$, zaś przyczepność do rur stalowych mieściła się w granicach od 4,3 MPa do 7,0 MPa (skład 2b).

15. Większość kamieni cementowych zawierających w składzie cement CEM III/A po 28 dniach sezonowania próbek odznaczała się mniejszą przepuszczalnością dla gazu, jednak nieznacznie większą porowatością w porównaniu z tymi samymi składami, ale na bazie cementów powszechnego użytku.

Analizując wyniki otrzymane dla zaczynów i kamieni cementowych wykonanych na bazie wody i oleju, można wysnuć następujące wnioski:

1. Zaczyny cementowe sporządzone na bazie cementu portlandzkiego posiadały niższe gęstości, od $1,62 \mathrm{~g} / \mathrm{cm}^{3}$ do $1,63 \mathrm{~g} / \mathrm{cm}^{3}$, w porównaniu z zaczynami z dodatkiem cementu glinowego, których gęstości wynosiły od $1,66 \mathrm{~g} / \mathrm{cm}^{3}$ do $1,68 \mathrm{~g} / \mathrm{cm}^{3}$.

2. Zastosowanie większej ilości upłynniacza, szczególnie powyżej $0,5 \%$ w zaczynach cementowych $\mathrm{z}$ dodatkiem oleju, nie miało większego wpływu na ich parametry.

3. Ze względu na większe trudności z ujednorodnieniem mieszaniny z dodatkiem cementu CEM I stosowano większy stosunek w/c.

4. Składy zawierające cement portlandzki miały nie tylko niższą gęstość, ale również odznaczały się bardzo wysoką filtracją, dochodzącą nawet do $296,0 \mathrm{~cm}^{3} / 30 \mathrm{~min}$ (skład 1), filtratem głównie była woda.

5. W wielu przypadkach podczas mieszania dochodziło do oddzielenia się niewchłoniętej wody lub oleju w postaci odstoju.

6. Słabe mieszanie oraz trudności z ujednorodnieniem mieszanin wpływały na bardzo niską elektryczną stabilność emulsji. Często wskaźnik ES był poniżej $3 \mathrm{~V}$.

7. Im wyższy wskaźnik ES, tym zaczyn cementowy dłużej wiązał oraz posiadał niższe wytrzymałości (skład 2, $\mathrm{ES}=24 \mathrm{~V}$, koniec wiązania: 7 dni, wytrzymałość na ściskanie po 28 dniach poniżej 2,2 $\mathrm{MPa}$ ).

8. Zastosowanie cementu glinowego wpłynęło na łatwiejsze i lepsze ujednorodnienie zaczynów cementowych z dodatkiem oleju. Dzięki temu można było zmniejszyć stosunek wodno-cementowy (w/c), co wpłynęło na wzrost 
gęstości oraz znaczne obniżenie filtracji zaczynów cementowych. W większości przypadków zaczyny nie posiadały odstoju.

9. Filtracja większości zaczynów zawierających cement glinowy wynosiła poniżej $3,0 \mathrm{~cm}^{3} / 30 \mathrm{~min}$, filtratem była emulsja wody i oleju.

10. Zaczyny opracowane na bazie cementu glinowego posiadały lepszą elektryczną stabilność, dochodzącą nawet do $156 \mathrm{~V}(\operatorname{skład} 7)$.

11. Obecność cementu glinowego wpłynęła na poprawę w ujednorodnieniu mieszanin, obniżenie filtracji, wzrost elektrycznej stabilności. Jednak otrzymane kamienie cementowe odznaczały się bardzo niską wytrzymałością na ściskanie.

12. Wytrzymałości kamieni cementowych na ściskanie po 28 dniach zarówno w $25^{\circ} \mathrm{C}$, jak i $120^{\circ} \mathrm{C}$ nie przekraczały 4,0 $\mathrm{MPa}$.

Po przeprowadzeniu szeregu badań laboratoryjnych dla wytypowanych składów w trzech różnych temperaturach oraz porównaniu ich z badaniami dla dwóch rodzajów cementów specjalnych, czyli łącznie 9 składów, można wyciągnąć pewne wnioski. Stosowane na przedgórzu Karpat przez serwisy cementacyjne cementy (CEM I oraz G) oraz opracowane składy zaczynów cementowych podczas zabiegów uszczelniania kolumn rur okładzinowych mają bardzo dobre parametry technologiczne. Zarówno parametry zaczynów cementowych, jak i otrzymanych z nich kamieni cementowych spełniają wszystkie specyficzne wymagania. Zaczyny cementowe posiadają odpowiednią rozlewność, gęstość, zerowy odstój wody oraz niską filtrację. Również czasy gęstnienia są odpowiednie, aby bezpiecznie zatłoczyć zaczyn do otworu wiertniczego bez obawy przed jego wcześniejszym związaniem. Badania parametrów mechanicznych kamieni cementowych wykonanych ze składów bazowych potwierdziły ich dobre właściwości w przypadku każdej temperatury. Wytrzymałości kamieni cementowych na ściskanie oraz przyczepność do rur stalowych wraz z upływem czasu były coraz wyższe, natomiast porowatości i przepuszczalności dla gazu intensywnie się obniżały.

Zastosowane cementy specjalne: portlandzki popiołowy CEM II/B-V oraz hutniczy CEM III/A nie są wykorzystywane w przemyśle naftowym do uszczelniania kolumn rur okładzinowych w otworach wiertniczych. Przeprowadzone badania wykazały, że zmiana cementu miała wpływ na każdy z mierzonych parametrów zaczynów i kamieni cementowych. Za- stosowanie cementu popiołowego w każdym przypadku wpłynęło na zmniejszenie rozlewności oraz gęstości zaczynów cementowych, wzrosła natomiast znacznie filtracja. Czasy gęstnienia w większości przypadków były zbliżone do tych z zaczynów bazowych. Otrzymane próbki kamieni cementowych charakteryzowały się dobrymi parametrami. Jedynie w temperaturze $25^{\circ} \mathrm{C}$ wyniki były nieznacznie niższe od tych otrzymanych z cementów powszechnie używanych, zaś w temperaturach $35^{\circ} \mathrm{C}$ i $45^{\circ} \mathrm{C}$ należały do najwyższych.

Zastosowanie cementu hutniczego CEM III/A wpłynęło na zmniejszenie gęstości zaczynów cementowych oraz w większości przypadków na obniżenie ich filtracji. Rozlewności zaczynów cementowych były zbliżone do tych, jakie posiadały zaczyny bazowe, jedynie w temperaturze $45^{\circ} \mathrm{C}$ uległy większemu obniżeniu. Badania czasów gęstnienia w przypadku każdego zaczynu wykazały, że były one znacznie dłuższe od tych, jakie charakteryzowały zaczyny na bazie cementów powszechnie stosowanych. Próbki kamieni otrzymanych z zaczynów cementowych z zawartością cementu hutniczego CEM III/A odznaczały się najsłabszymi parametrami mechanicznymi spośród wszystkich przebadanych, zarówno z cementami powszechnie stosowanymi CEM I i G, jak i specjalnym CEM II/B-V, mimo to były również wysokie.

Przeprowadzone badania laboratoryjne wykazały, że wykorzystanie cementów specjalnych ma zarówno pozytywny, jak i negatywny wpływ na parametry zaczynów i kamieni cementowych. Porównanie dwóch cementów specjalnych z cementami powszechnie stosowanymi na podstawie składów zaczynów cementowych używanych przez serwisy cementacyjne wykazało, że każdy z cementów można z powodzeniem stosować podczas uszczelniania kolumn rur okładzinowych.

Wstępne badania przeprowadzone nad możliwością opracowania składów zaczynów cementowych na bazie wody i oleju w tym przypadku wykazały, że pod względem parametrów zaczynów cementowych lepszy okazał się cement glinowy. Zastosowanie go wpłynęło na obniżenie filtracji oraz znaczny wzrost elektrycznej stabilności emulsyjnej zaczynów cementowych. Ujednorodnienie mieszaniny oraz wspólne łączenie się poszczególnych dodatków nie stwarzało większych trudności. Jedynie wytrzymałości otrzymanych kamieni cementowych są bardzo niskie, dlatego niezwykle istotne jest prowadzenie dalszych szczegółowych badań nad doborem odpowiednich receptur.

Prosimy cytować jako: Nafta-Gaz 2018, nr 2, s. 96-105, DOI: 10.18668/NG.2018.02.03

Artykuł nadesłano do Redakcji 24.11.2017 r. Zatwierdzono do druku 4.01.2018 r.

Artykuł powstał na podstawie pracy statutowej pt.: Badania nad możliwościa zastosowania cementów specjalnych do uszczelniania kolumn rur okładzinowych - praca INiG - PIB na zlecenie MNiSW; nr zlecenia 0057/KW/17/01; nr archiwalny: DK-4100-44/17. 


\section{Literatura}

[1] Abu-Khamsin S.A.: Basic Properties of Reservoir Rocks. King Fahd University of Petroleum \& Minerals, Dhahran, Saudi Arabia, 2004.

[2] Alford P., Anderson D., Bishop M., Goldwood D. i in.: Novel Oil Based Mud Additive Decreases HTHP Fluid Loss and Enhances Stability. AADE-14-FTCE-18, 2014.

[3] Dębińska E.: Ocena działania dodatków opóźniajacych czas wiązania zaczynów cementowych na podstawie badań laboratoryjnych. Nafta-Gaz 2012, nr 4, s. 225-232.

[4] Dudek J., Dudek L., Klimek P.: Badania ekshalacji gazu w rejonie złoża Przeworsk. Prace Instytutu Górnictwa Naftowego i Gazownictwa nr 130, 2004.

[5] Fernandez J., Sharp K., Plummer D.: Enhanced Fluid Viscosity Using Novel Surfactant Chemistry Purposely Designed for Low-Aromatic Mineral and Synthetic Base Fluids. AADE-14FTCE-15, 2014.

[6] Giergiczny Z. i in.: Cementy w ofercie handlowej Górażdże Cement S.A. Chorula, październik 2003.

[7] Instrukcja obsługi przepuszczalnościomierza firmy OFITE. Model 120-87.

[8] Jasiński B.: Badania nad zastosowaniem emulsji olejowo-wodnych jako cieczy roboczych o obniżonej gęstości. Nafta-Gaz 2012, nr 12, s. 1155-1164.

[9] Kremieniewski M.: Modyfikacja przestrzeni porowej kamieni cementowych. Nafta-Gaz 2012, nr 3, s. 165-170.

[10] Kremieniewski M.: Wpływ warunków hydratacji na strukture przestrzenna kamieni cementowych. Nafta-Gaz 2013, nr 1, s. $51-56$
[11] Kremieniewski M., Stryczek S., Kotwica L.: Zmiany w mikrostrukturze plaszcza cementowego w zależności od warunków hydratacji zaczynu. Nafta-Gaz 2014, nr 12, s. 918-925.

[12] Kurdowski W.: Chemia cementu i betonu. Wydawnictwo Naukowe PWN, Warszawa 2010.

[13] Kut Ł.: Wplyw mikrocementu na parametry zaczynu i kamienia cementowego. Nafta-Gaz 2011, nr 12, s. 903-908.

[14] Vipulanandan C., Krishnamoorti R.: Smart cementing materials and drilling muds for real time monitoring of deepwater wellbore enhancement. CIGMAT University of Huston, kwiecień 2013.

\section{Akty prawne i normatywne}

[15] PN-B-19707 Cement. Cement specjalny. Skład, wymagania i kryteria zgodności, 2013.

[16] PN-EN ISO 10426-2 Cementy i materiaty do cementowania otworów wiertniczych. Część 2: Badania cementów wiertniczych, 2006.

[17] PN-EN-14647 Cement glinowo-wapniowy. Sktad, wymagania i kryteria zgodności, 2007.

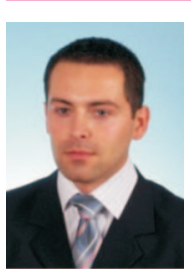

Mgr inż. Łukasz KUT

Asystent w Zakładzie Technologii Wiercenia. Instytut Nafty i Gazu - Państwowy Instytut Badawczy ul. Lubicz 25 A

31-503 Kraków

E-mail:lukasz.kut@inig.pl

\section{OFERTA}

\section{ZAKŁAD ANALIZ NAFTOWYCH}

Zakres działania:

- kompleksowa analiza rop naftowych;

- badanie składu chemicznego i ocena jakości produktów naftowych, biokomponentów, biopaliw, paliw alternatywnych;

- ocena potencjalnej kancerogenności produktów naftowych, w tym test DAB-10;

- oznaczanie metali ciężkich w produktach naftowych świeżych i zużytych oraz w odpadach;

- identyfikacja substancji pochodzących z degradacji produktów naftowych;

- $\quad$ usługi: monitorowania jakości paliw ciekłych i biopaliw, monitorowania jakości LPG, monitorowania stopnia zużycia olejów silnikowych w pojazdach;

- opracowywanie nowych metod analitycznych dla produktów naftowych i pokrewnych: świeżych, w eksploatacji i zużytych;

- $\quad$ identyfikacja i oznaczanie toksycznych związków emitowanych z silników wysokoprężnych (WWA w cząstkach stałych PM);

- $\quad$ usługi eksperckie i rzeczoznawcze w zakresie: orzecznictwa o jakości paliw silnikowych, analityki produktów naftowych, problemów związanych z eksploatacją produktów naftowych i produktów pokrewnych;

- $\quad$ badania i doradztwo w zakresie klasyfikacji surowców i produktów naftowych w odniesieniu do Nomenklatury Scalonej (CN);

- $\quad$ opracowanie kart charakterystyki substancji niebezpiecznych dla branży naftowej i branż pokrewnych;

- $\quad$ badania odporności rop naftowych i paliw na przechowywanie w kawernach solnych.

Kierownik: dr inż. Beata Altkorn

Adres: ul. kukasiewicza 1, 31-429 Kraków

Telefon: 126177500

Faks: 1261776 80, 126177522

E-mail: beata.altkorn@inig.pl 